\title{
Uni Emirat Arab: Kuasa Ekonomi di Timur Tengah (2002-2018)
}

\section{United Arab Emirates: Economic Power in the Middle East (2002-2018)}

\author{
Khaeruddin $^{1}$, Syahrul Hidayat ${ }^{2}$ \\ $1 \bowtie{ }^{2}$ Universitas Negeri Makassar \\ E-mail:khaeruddinfis@unm.ac.id ${ }^{凶}$, syahrulhidhar07@gmail.com
}

Diterima: 09 November 2020 | Direvisi: 13 November 2020 | Diterbitkan: 16 November 2020

\section{ARTICLE INFO}

\section{Keywords:}

Middle East,

United Arab Emirates,

Economic.

\section{Kata Kunci: \\ Timur Tengah, \\ Uni Emirat Arab, \\ Ekonomi.}

\section{ABSTRACT}

The United Arab Emirates is known worldwide as a symbol of globalization and as a gateway to the Arab region and beyond as well as a bridge between East and West. The United Arab Emirates has a source of wealth derived from petroleum and mineral mines which are useful for development in the United Arab Emirates. The purpose of this article is to discuss the economic power of the United Arab Emirates in the Middle East. Meanwhile, the method used in this research is the historical research method with 4 stages, namely heuristics, source criticism, interpretation, and historiography. The results of the study found that the United Arab Emirates is the second richest country in the Middle East with its petroleum and mineral mining wealth which makes this country a very high economy under Qatar. However, the United Arab Emirates does not only depend on this sector, but also on other sectors, such as SMEs, plantations, infrastructure, and tourism. This country has practically experienced no significant impact due to the economic crisis and the global economic slowdown.

Uni Emirat Arab (UEA) terkenal di dunia sebagai lambang globalisasi dan sebagai pintu untuk masuk wilayah Arab dan sekitarnya serta sebagai jembatan antara Timur dan Barat. UEA memiliki sumber kekayaan yang berasal dari minyak bumi dan tambang mineral yang berguna untuk pembangunan di UEA. Tujuan dari artikel ini adalah untuk membahas tentang kuasa ekonomi UEA di Timur Tengah. Sedangkan, metode yang digunakan dalam penelitian ini adalah metode penelitian sejarah dengan 4 tahapannya, yakni heuristik, kritik sumber, interpretasi, dan historiografi. Hasil penelitian menemukan bahwa UEA sebagai negara kedua yang kaya di Timur Tengah dengan kekayaan minyak bumi dan tambang mineralnya yang membuat negara ini memiliki perekonomian yang sangat tinggi di bawah Qatar. Namun, UEA tidak hanya bergantung pada sektor tersebut, melainkan juga pada sektor lain, seperti UKM, perkebunan, infrastruktur, dan pariwisata. Negara ini praktis tidak mengalami dampak signifikan akibat krisis ekonomi dan perlambatan perekonomian global.

\section{PENDAHULUAN}

Bagi sebagian besar orang awam, hal-hal pertama yang mungkin muncul di benaknya ketika pertama kali mendengar istilah Timur Tengah (Middle East) adalah daerah konflik bersenjata, perselisihan Arab-Israel, dan pusat kegiatan terorisme. Orang-orang juga seringkali teringat bahwa daerah ini merupakan daerah yang sangat kaya akan minyak bumi. Sepintas lalu, seringkali Timur Tengah diidentikkan dengan kawasan jazirah Arabia. Pada dasarnya, anggapan-anggapan itu tidaklah keliru, hanya 
saja terkesan agak dangkal. Sebagian besar orang awam banyak yang belum memahami pengertian yang terkandung dari istilah Timur Tengah itu sendiri, khususnya mengenai apakah istilah itu sebenarnya merupakan penamaan geografis ataukah merupakan suatu penamaan secara geopolitik, dan negara-negara mana saja yang termasuk di dalamnya.

Secara geografis, definisi Timur Tengah tidak begitu jelas. Tapi para sejarawan sepakat menyatakan bahwa yang dimaksud dengan Timur Tengah adalah wilayah yang terbentang antara Lembah Nil (The Nile Valley) hingga negeri-negeri Muslim di Asia Tengah (lebih kurang Lembah Amur Darya atau Sungai Oxus), dari Eropa yang paling tenggara hingga lautan Hindia. Negeri-negeri Muslim di Asia yang ada di dalamnya sering juga disebut dengan Timur Dekat (The Near Asia) dan khusus bagian Benua Asia biasa juga disebut dengan Asia Barat (West Asia). Amerika Serikatlah yang mempopulerkan istilah Timur Tengah setelah Perang Dunia II (Istadiyantha, 2010).

Timur Tengah bagi kalangan ilmuwan politik dipandang sebagai sebuah daerah yang masih sulit untuk dideskripsikan. Beragam pandangan hadir untuk menjawab letak sebenarnya daerah Timur Tengah. Dalam perkembangannya, kalangan ilmuwan politik memiliki tiga pandangan terkait Timur Tengah. Pertama, daerah yang meliputi negara-negara Arab-NonAfrika ditambah Iran dan Israel. Dalam pengertian ini, negara semisal Alzajair dan Maroko tidak termasuk di dalamnya. Kedua, daerah Timur Tengah meliputi negara-negara Liga Arab ditambah Iran, Israel, dan Turki. Jadi, daerah-daerah yang berbahasa maupun yang berbudaya Arab seperti beberapa terletak di daerah Afrika Utara (Aljazair, Maroko, Libya) dikategorikan masuk ke dalam wilayah Timur Tengah. Ketiga, wilayah yang menjadi lokus kedua pandangan sebelumnya ditambah negara semisal Afganistan, Pakistan, dan beberapa republik Muslim yang ada di Asia Tengah bekas jajahan Uni Soviet (Ruslin, 2013).

Sementara pandangan lain mengatakan bahwa Timur Tengah adalah sebuah wilayah yang secara politis, dan budaya merupakan bagian dari benua Asia, atau Afrika-Eurasia. Pusat dari wilayah ini adalah daratan di antara Laut Mediterania dan Teluk Persia serta wilayah yang memanjang dari Anatolia, Jazirah Arab dan Semenanjung Sinai. Kadangkala disebutkan juga area tersebut meliputi wilayah dari Afrika Utara di sebelah barat sampai dengan Pakistan di sebelah timur, dan Kaukasus dan/atau Asia Tengah di sebelah utara. Media, dan beberapa organisasi internasional, seperti PBB umumnya menganggap wilayah Timur Tengah adalah wilayah Asia Barat Daya, termasuk Siprus dan Iran ditambah dengan Mesir (Tumanggor, 2018).

Dinamika Timur Tengah memang selalu memberikan banyak pengaruh terhadap stabilitas internasional. Kawasan yang berada di antara Asia dan Eropa, dikenal sebagai kawasan yang banyak konflik dan peperangan. Namun, di balik kondisi politik kawasan yang begitu rumit, setidaknya Timur Tengah memiliki dua potensi yang memiliki nilai cukup tinggi. Kedua potensi tersebut adalah kekayaan minyak yang terkandung di bawah wilayah negaranegara Arab dan juga lokasi strategis untuk berbagai kepentingan (Bafadal, 2018).

Timur Tengah memiliki lebih dari setengah total cadangan minyak di seluruh dunia, dan menjadi penentu pasar minyak dunia. Cadangan 
terbesar ada di Arab Saudi yang memiliki sekitar 36 persen dari total cadangan minyak di Timur Tengah. Disusul Irak 16 persen, UEA 14 persen, Iran 13 persen, Kuwait 13 persen, Libya 4 persen, Oman 1 persen, Qatar 1 persen, Yaman 1 persen, dan Aljazair 1 persen (Balat, 2006).

Kawasan Timur Tengah (Middle East) selalu menarik untuk dibicarakan, dijadikan bahasan, dan objek penelitian. Hal itu karena Timur Tengah memiliki posisi strategis dalam pertimbangan geopolitik, baik pada masa kolonialisme maupun setelahnya (Wibowo, 2010). Timur Tengah adalah istilah geografis yang fleksibel, yang berubah menurut era dan penggunaannya. Timur Tengah pada awalnya merupakan istilah yang diciptakan pada akhir abad ke-19 oleh Inggris, bersama dengan istilah geografis Eropa-sentris lainnya, seperti Timur Dekat (wilayah Mediterania timur yang paling dekat dengan Eropa) dan Timur Jauh (China, Jepang, Korea, dan entitas Asia Timur lainnya yang lebih jauh dari Eropa). Timur Tengah pada saat itu didefinisikan sebagai wilayah yang terletak di antara dua titik ekstrem ini: Semenanjung Arab, Mesopotamia, dan Persia dan wilayah Asia Tengah. Istilah Timur Dekat agak tidak disukai, tetapi umumnya digunakan secara bergantian dengan istilah Timur Tengah. Kawasan Timur Tengah lalu meluas ke arah barat, sehingga melingkupi Mediterania Timur dan Afrika Utara (Padjadjaran, n.d.).

Salah satu negara yang ada di Timur Tengah adalah Uni Emirat Arab (UEA). UEA merupakan negara federasi yang terdiri dari 7 wilayah, masing-masing dipimpin oleh seorang emir. Ketujuh wilayah tersebut adalah: Abu Dhabi, Dubai, Sharjah, Ajman, Umm al-Quwain,
Fujairah, Ras al-Khaimah. Abu Dhabi merupakan ibu kota negara UEA (ITPC DUBAI UNITED ARAB EMIRATES MARKET BRIEF 2013, n.d.).

UEA berdiri pada 2 Desember 1971 setelah Inggris menarik pasukannya dari wilayah Teluk. Letak geografis UEA sangat strategis sehingga memungkinkan para pedagang dari wilayah India yang akan ke Timur Tengah maupun Eropa melewati wilayah Teluk Arab. UEA menjadi pusat perdagangan mutiara dan jalur perdagangan antara kawasan Asia dengan kawasan Eropa. Pada saat ini, peran UEA tersebut berkembang menjadi tempat transit penerbangan internasional, pelabuhan internasional, jalur pipa minyak internasional serta pusat bisnis untuk wilayah Timur Tengah (Pratama, 2004). Negara mempunyai sifat khusus yang merupakan manifestasi dari kedaulatan yang dimilikinya dan yang hanya terdapat pada negara saja dan tidak terdapat pada asosiasi atau organisasi lainnya. Dalam bentuk negara federasi, pemerintah pusat dengan pemerintah daerah sama-sama berdaulat (Budiardjo, 2003).

UEA merupakan suatu wilayah yang dikelilingi oleh hamparan padang pasir yang luas di pesisir Teluk Persia, dan masing-masing emirat bertanggung jawab atas perekonomiannya. Dengan keadaan geografis tersebut penduduk di sana kemudian mengandalkan laut sebagai sumber kehidupan mereka termasuk dengan perekonomian mereka, dan menangkap ikan serta mencari mutiara menjadi sumber penghidupan penduduk pada saat itu (Sejarah dan Perkembangan Uni Emirat Arab, n.d.). 
UEA merupakan salah satu negara yang mengalami ekspansi ekonomi yang cepat serta pertumbuhan penduduk yang tinggi. Berdasarkan data dari IMF, pada tahun 2013, GDP nominal UEA menempati urutan kedua dalam CCASG (setelah Arab Saudi), ketiga di Timur Tengah \& Afrika Utara (MENA) (setelah Arab Saudi dan Iran), dan 30 di dunia. Berdasarkan laporan terbaru dari Kementerian Keuangan UEA, GDP nominal UEA mengalami kenaikan sebesar 4 persen pada 2013 menjadi US\$ 383 miliar bila dibandingkan dengan GDP tahun sebelumnya (ITPC DUBAI - UNITED ARAB EMIRATES MARKET BRIEF 2013, n.d.). Berdasarkan uraian di atas, artikel ini dibuat sebagai upaya untuk memperoleh gambaran secara menyeluruh dan mendalam mengenai kuasa ekonomi di Timur Tengah, khususnya di UEA.

\section{METODE}

Metode yang digunakan dalam penelitian ini adalah penelitian sejarah. Metode sejarah dapat diartikan sebagai cara atau prosedur yang sistematis dalam merekonstruksi masa lampau. Metode ini terdiri atas empat tahap, yaitu: 1) Heuristik, tahap mencari dan mengumpulkan sumber-sumber sejarah yang terkait dengan topik penelitian; 2) Kritik sumber, tahap untuk mengetahui keabsahan suatu sumber atau data yang didapatkan. Kritik tersebut berupa kritik tentang otentitasnya (kritik eksternal) maupun kredibilitas isi (kritik internal). Kritik ini dilakukan ketika dan sesudah pengumpulan data berlangsung. Sumber sejarah yang telah dikritik menjadi data sejarah; 3) Interpretasi, dilakukan terhadap fakta sejarah yang diperoleh dalam bentuk penjelasan terhadap fakta sejarah tersebut dengan seobjektif mungkin. Dalam interpretasi, fakta-fakta sejarah dapat diuraikan dan disatukan sehingga mempunyai makna yang berkaitan satu dengan yang lainnya; 4) Historiografi, langkah terakhir dalam penulisan. Penjelasan berbagai fakta yang ditemukan sehingga menjadi narasi sejarah yang dapat dipertanggungjawabkan (Ananda \& Bosra, 2019; Kuswono, Saputra, \& Agustono, 2019; Sejarah, 2013).

\section{HASIL DAN PEMBAHASAN}

\section{Letak Geografis dan Sejarah Singkat UEA}

UEA terletak di Semenanjung Arab dengan luas $83.600 \mathrm{~km}^{2}$. Negara tersebut bersebelahan dengan Oman di sisi timur dan Saudi Arabia di sisi barat. Negara UEA terdiri dari tujuh federasi yaitu Abu Dhabi, Dubai, Ras Al Khaimah, Sharjah, Ajman, Fujairah, dan Umm al-Qaiwan. Abu Dhabi adalah federasi yang terbesar dan sekaligus menjadi ibukota negara UEA. Industri minyak dan gas terbesar di UEA ada di Abu Dhabi, diikuti oleh Dubai, Sharjah dan Ras al Khaimah. Sementara Dubai adalah pusat bisnis perniagaan, perbankan, dan turisme UEA (Wening, 2010).

Sejarah peradaban di UEA diawali dari penemuan artefak kuno yang menunjukan bahwa terdapat sejarah panjang peradaban manusia dan perdagangan di UEA. Bukti arkeologi menyebutkan bahwa peradaban di wilayah UEA telah ada sejak Zaman Neolitik atau Palaeolitik (6000 SM- 3500 SM), Zaman Perunggu (2600SM - 2000 SM), sampai dengan Zaman Besi (1300 SM-300 SM). Inggris yang menguasai UEA menjadi tonggak penting perkembangan bangsa dan negara ini yang dimulai pada abad ke-19. Namun, sebelum itu 
negara ini juga dijajah oleh beberapa negara Barat seperti Portugis dan Belanda. Portugis pertama kali menjajah negara teluk sekitar tahun 1498, saat itu, Portugis menguasai pasar rempah-rempah di sana selama satu setengah abad yang kemudian digantikan oleh Belanda. Setelah melemahnya kekuatan Belanda, Inggris pun masuk dengan membuat perjanjian dengan negara teluk pada tahun 1892. Perjanjian tersebut berisi kesepakatan para syekh untuk tidak melakukan hubungan dengan negara asing lain kecuali dengan persetujuan Inggris dan sebagai timbal baliknya Inggris akan menjaga wilayah Pantai Trusial dari serangan melalui laut serta akan membantu jika terjadi serangan darat. Pada era ini mata pencaharian utama bagi penduduk di wilayah Pantai Trusial adalah budidaya mutiara, masa itu mutiara dari wilayah Timur Tengah merupakan komoditas yang sangat menjanjikan di pasar. Namun, akibat adanya Perang Dunia I industri mutiara di wilayah itu mengalami kemunduran sekitar tahun 1930-an, yang diperparah dengan ditemukannya mutiara hasil budidaya Jepang yang kemudian menguasai pasar. Industri mutiara di wilayah Pantai Trusial pun benarbenar mati setelah Perang Dunia II (Sejarah dan Perkembangan Uni Emirat Arab, n.d.).

Namun setelah masa sulit tersebut, negara teluk ini menemukan sebuah titik terang dengan ditemukannya sumber minyak di kawasan Teluk Persia pada tahun 1958 dan di padang pasir di Murban pada tahun 1960. Kargo minyak mentah pertama diekspor dari Jabel Dhanna di Abu Dhabi pada tahun 1962. Ketika pendapatan minyak meningkat, penguasa Abu Dhabi, Sheikh Zayed bin Sultan Al Nahyan, melakukan sebuah program pembangunan besar-besaran, yakni membangun sekolah, perumahan, rumah sakit dan jalan. Ketika ekspor minyak Dubai dimulai pada tahun 1969, Sheikh Rashid bin Saeed Al Maktoum, penguasa Dubai, juga dapat menggunakan pendapatan minyak untuk meningkatkan kualitas hidup rakyatnya. Perkembangan pesat emirat pada masa itu membuat pemerintah Inggris merasa sudah tidak dapat lagi mengatur UEA, hal tersebut kemudian ditambah dengan melemahnya kekuatan Inggris pada tahun 1966. Para anggota parlemen Inggris pun berpendapat bahwa Inggris sudah tidak mampu lagi menjaga wilayah pantai Trusial karena kemunduran yang dialami oleh angkatan laut Inggris. Oleh karena itu Inggris pun memutuskan untuk mengakhiri perjanjian mereka dengan negara teluk pada tanggal 24 Januari 1968. Keputusan tersebut kemudian diperkuat lagi oleh Perdana Menteri Inggris Edward Heath pada bulan Maret 1971. Sheikh Zayed pun mencoba untuk kembali bernegosiasi dengan pemerintah Inggris untuk tetap mempertahankan angkatan bersenjata Inggris di Emirates dan menawarkan biaya penuh untuk membayar kesepakatan tersebut, namun pemerintah Inggris tetap pada keputusannya untuk mengakhiri perjanjian. Dengan berkahrinya perjanjian Inggris dengan negara-negara teluk, membuat negara-negara teluk menjadi mandiri sepenuhnya. Sebagai tindak lanjut dari kemerdekaan negara-negara teluk dari Inggris, mereka memutuskan untuk bergabung membuat suatu federasi. Pada tahun 1971 enam emirat, yaitu Abu Dhabi, Dubai, Sharjah, Ajman, Fujairah, dan Umm Al Quwain melakukan penandatanganan perjanjian 
Khaeruddin, Hidayat, 2020, Uni Emirat Arab ...

pendirian UEA. Keputusan tersebut diikuti oleh Ras Al Khaimah yang turut bergabung pada tahun 1972 yang melengkapi susunan federasi UEA seperti yang dikenal sampai saat ini (Sejarah dan Perkembangan Uni Emirat Arab, n.d.).

\section{Perekonomian UEA}

Timur Tengah seolah tak pernah lepas dari perang dan konflik. Selama beberapa dekade terakhir ada sejumlah perang yang terjadi di Timur Tengah, mulai dari Perang Iran-Irak (1980-1988), perang koalisi AS melawan Irak (1991 dan 2003), Perang Israel melawan warga Gaza (2008-2009, dan 2012), dan perang di Lebanon (1982, dan 2006). Sejak 2010, terjadi pula fenomena yang kerap disebut Arab Spring, dimulai dari penggulingan rezim di Tunisia (2010) dan Mesir (2011), penggulingan Qaddafi oleh milisi bersenjata lokal yang dibantu NATO (2011), dan perang berkepanjangan di Suriah (mulai 2011 hingga kini), serta agresi Arab Saudi ke Yaman (sejak 2015 hingga kini) (Pradana \& Yulianti, 2017). Konflik yang terjadi di Timur Tengah kian memanas. Konflik ini terus berdampak luas dan sudah melanda kawasan Qatar. Bahkan, 7 negara-negara Teluk Arab, yakni UEA, Mesir, Arab Saudi, Bahrain,Yaman, dan dua negara lainya memutuskan hubungan diplomatiknya (Triyono, 2018).

Kawasan Timur Tengah merupakan salah satu wilayah yang memliki potensi yang besar jika dilihat dari sudut pandang geopolitik dan geostrateginya. Terdapat banyak faktor yang membuat kawasan Timur Tengah ini menjadi rebutan bangsa-bangsa besar seperti Amerika, Inggris dan Prancis. Beberapa keistimewaan yang terkandung di dalamnya termasuk wilayah ini menjadi penghubung tiga benua: Asia, Afrika, dan Eropa. Timur Tengah adalah negeri diturunkannya tiga agama besar, yaitu Yahudi, Nasrani dan Islam. Faktor agama ini juga merupakan salah satu keistimewaan bagi Timur Tengah. Timur Tengah sepanjang sejarah sangat dikenal sebagai tanah kelahiran Nabi yang kemudian dianggap sebagai tempat yang suci dan mendorong setiap umat untuk mempertahankan wilayahnya. Faktor penting banhwa kawasan ini kaya dengan minyak, serta minyak pulalah yang menjadi faktor sangat penting, sehingga negara-negara industri seperti Amerika, Perancis, Inggris menjadi semakin terdorong untuk menguasai kawasan ini dengan segala cara (Raharjo \& Jamal, 2018). Sejak ilmu ekonomi berkembang di dunia, masalah pertumbuhan ekonomi telah banyak diteliti oleh para ilmuwan barat maupun ilmuwan muslim yang menghasilkan banyak teori dan aliran ekonomi (Insani \& Indra, 2015).

UEA merupakan sebuah megara yang awalnya hidup dari ketergantungan pada minyak dan gas, lalu berhasil mengembangkan bisnis baru di bidang real estate, pariwisata, olahraga kelas dunia, keuangan, dan pembangunan (Grant, Golawala, \& McKechnie, 2007). Sebagai negara-negara penghasil minyak, negaranegara di Timur Tengah menjadi tujuan utama bagi para profesional yang bekerja di sektor tambang (Safitry \& Haryanto, 2019). Dalam perdagangan internasional, kegiatan ekspor menjadi andalan bagi negara-negara di dunia untuk meningkatkan pertumbuhan ekonomi, termasuk bagi Indonesia (Paryadi, 2019). Negara dengan perkembangan ekonomi yang sangat pesat mencapai 5\% pada tahun 2014 yang awalnya hanya diprediksikan 3,9\% saja. Negara teluk yang paling transparan dalam 
peringkat korupsi, sehingga menarik para investor baik asing maupun dalam negeri (Rohman, 2017).

Selama abad 19, industri mutiara laut menjadi sumber perekonomian yang berkembang di wilayah pesisir Teluk Persia. Hasil dari industri mutiara laut tersebut berkembang pesat hingga diekspor ke berbagai wilayah, salah satunya ke India. Namun, perkembangan industri mutiara tersebut tidak berlangsung lama karena terjadinya Perang Dunia I yang berdampak pada perdagangan mutiara. Bahkan, benar-benar hilang setelah terjadinya Perang Dunia II. Namun, berakhirnya industri mutiara di pesisir Teluk Persia tidak menjadi akhir dari perkembangan perekonomian negara-negara emirat. Sebaliknya pada tahun 1930-an dilakukan penelitian pertama di wilayah Teluk untuk menemukan sumber daya minyak di sana. Minyak ditemukan di Teluk Persia, Umm Shaif, pada tahun 1958, dan di padang pasir Murban pada tahun 1960 (Sejarah dan Perkembangan Uni Emirat Arab, n.d.).

Penemuan sumber minyak di wilayah teluk menjadi titik awal kebangkitan ekonomi di negara teluk. Abu Dhabi pun mulai mengekspor minyak hasil produksinya pada tahun 1962, hal tersebut menjadi awal mula transformasi wilayah tersebut yang semula hanya kawasan gurun yang miskin menjadi wilayah yang maju dan modern. Namun, kemajuan tersebut baru dirasakan oleh dua emirat, yaitu Dubai dan Abu Dhabi karena penemuan minyak tersebut terjadi sebelum kemerdekaan UEA, ketika semua emirat bertanggung jawab atas perekonomian masing-masing. Angka produksi dan cadangan minyak di UEA saat itu sebagian besar bersumber pada Abu Dhabi dan Dubai. Oleh karena itu, setelah kemerdekaan dan tergabungnya emirat-emirat dalam satu negara yaitu UEA, munculah satu tujuan untuk memperbaiki kehidupan di wilayah-wilayah lain yang belum terjangkau. Perbaikan dan pembangunan di wilayah-wilayah emirat pun kemudian dilakukan oleh pemerintah UEA dengan bantuan ekonomi dari pendapatan Dubai dan Abu Dhabi di sektor minyak. Setelah ditemukannya minyak, UEA memang mengalami perubahan yang signifikan dalam berbagai bidang terutama dalam segi perekonomian (Sejarah dan Perkembangan Uni Emirat Arab, n.d.).

Produksi minyak meningkat dari 253 mineral per barel pada tahun 1970 menjadi sekitar 619 mineral per barel. Pada tahun 1975 ekspor meningkat dari 253 mineral per barel menjadi sekitar 606 mineral per barel dan pendapatan minyak melonjak dari US\$233 juta menjadi US\$ 600 juta. Pertumbuhan pendapatan minyak yang sangat besar selama periode 1970-1975 (sekitar 2475 \%) merupakan hasil dari peningkatan produksi dan penyesuaian dalam pengambilan pemerintah. Harga minyak yang meningkat antara tahun 2002 dan pertengahan 2008 memperkuat dominasi pendapatan minyak di ekonomi GCC. Pangsa minyak dalam ekonomi meningkat dari 30,8 persen PDB pada tahun 2002 menjadi 40 persen pada tahun 2006. Pendapatan minyak berubah 86 persen dari total pendapatan pemerintah pada tahun 2006 dibandingkan dengan angka pendapatan pemerintah pada tahun 2002, yakni 77,4 persen. Selama periode yang sama, kontribusi minyak untuk pelabuhan juga meningkat dari 61 menjadi 
Khaeruddin, Hidayat, 2020, Uni Emirat Arab ...

67 persen. Angka-angka ini menunjukkan bahwa walaupun terdapat upaya diversifikasi, negara-negara GCC semakin bergantung pada sumber tunggal untuk menghasilkan pendapatan, sehingga membuat mereka terus rentan terhadap fluktuasi harga minyak (Sejarah dan Perkembangan Uni Emirat Arab, n.d.).

Hingga tahun 2009 keberadaan minyak dan gas bumi di UEA masih terus memainkan peran penting dalam berjalannya roda perekonomian. Namun pada tahun 2011 penggalakan diversifikasi ekonomi mulai diupayakan di UEA, khususnya di Dubai yang telah bangkit dari krisis ekonomi tahun 2007 hingga 2010 lalu. Upaya pengurangan ketergantungan negara terhadap minyak terus dilakukan oleh pemerintah UEA dengan berbagai proyek yang dibangun, salah satunya ialah pembangunan Pelabuhan Khalifa di Emirat Abu Dhabi pada akhir 2012. Pada tahun 2012, UEA berhasil menempati posisi kedua negara dengan ekonomi terbesar di dunia dengan PDB US\$ 377 miliar. Hal tersebut didukung oleh pertumbuhan perdagangan sektor non-migas di UEA yang juga terus mengalami peningkatan. Peningkatan tersebut tersebut terus berlanjut hingga pada saat perlambatan ekonomi terjadi di kawasan Timur Tengah pada tahun 2014. Adanya perlambatan ekonomi tersebut dipicu oleh jatuhnya harga minyak dunia, sedangkan minyak merupakan sumber pendapatan utama sebagian besar kawasan di Timur Tengah (Sejarah dan Perkembangan Uni Emirat Arab, n.d.).

Namun, justru pada tahun 2014, UEA mengalami peningkatan pada pertumbuhan ekonominya hingga mencapai angka 4,8 persen, angka tersebut lebih dari perkiraan sebelumnya.
Peningkatan tersebut berhasil dicapai karena kinerja kuat sektor-sektor non-migas UEA yang meliputi sektor perbankan dan keuangan, manufaktur dan real estate, penerbangan, pariwisata, perhotelan, serta perdagangan dan jasa. Pada sektor perdagangan luar negeri, UEA termasuk dalam 20 negara dengan impor terbesar di dunia dan dan juga termasuk 16 negara eksportir terbesar di dunia, kedudukan tersebut membuat UEA menjadi negara dengan perdagangan luar negeri yang cukup dinamis. Pertumbuhan sektor ekspor-impor barang dan jasa di UEA dari tahun ke tahun menunjukan kecenderungan yang cukup stabil. Adapun sektor lain yang turut mendorong peningkatan pertumbuhan ekonomi UEA yaitu dari sektor UKM yang menyumbang sekitar 60 persen dari GDP UEA. Adanya peningkatan di semua sektor non-migas tersebut berhasil membantu UEA dalam perekonomiannya di tengah terjadinya fallouts yang dipicu oleh jatuhnya harga minyak dunia. IMF telah merevisi proyeksi kenaikan pertumbuhan untuk UEA. Perekonomian UEA diproyeksikan akan mengalami pertumbuhan lebih dari 4,5 persen pada tahun 2015, didukung oleh percepatan diversifikasi non-migas negara ini, peningkatan pengeluaran pemerintah, dan meningkatnya arus investasi asing langsung (Sejarah dan Perkembangan Uni Emirat Arab, n.d.).

Catatan Bank Dunia juga menunjukkan besarnya GDP negara yang beribu kota di Abu Dhabi ini pada 2015 yakni mencapai US\$ 370,29 miliar. Sementara GDP UEA pada tahun 2016 adalah sebesar US\$ 669,7 miliar (HN, 2016). UEA memiliki PDP tahun 2017 sebesar US $\$ 70.570$ (Citradi, 2019). PDP Nominal UEA dilaporkan sebesar US\$421,1 
miliar pada 2019. Rekor ini turun dibanding sebelumnya yaitu $\$ 422,2$ miliar untuk 2018 (“Uni Emirat Arab PDB Nominal," 2020). UEA menempati posisi kedua setelah Qatar dengan pendapatan per kapita hingga US $\$ 44.770$ dengan PDB yang lebih besar dari Qatar, yakni sebesar US\$440,181 miliar (Lestari, 2020).

\section{KESIMPULAN}

UEA sebagai negara kedua yang kaya di Timur Tengah yang dikenal dengan kekayaan minyak bumi dan gas alamnya yang membuat negara ini memiliki perekonomian yang sangat tinggi di bawah Qatar. UEA tidak hanya bergantung pada produksi minyak mentah, melainkan juga pada sektor lain seperti sektor UKM, perkebunan, infrastruktur, dan pariwisata. Negara ini praktis tidak mengalami dampak signifikan akibat krisis ekonomi dan perlambatan perekonomian global.

\section{DAFTAR PUSTAKA (Tahoma, Bold, Ukuran}

\section{1, Spasi 1,5)}

Ananda, R., \& Bosra, M. (2019). Yayasan Pendidikan Islam Tompobulu, 1962-2010. Jurnal Pattingalloang, 6(3), 88-95.

Bafadal, I. M. I. (2018). Motif Dibalik Pengembangan Industri Penerbangan Uni Emirat Arab. Jurnal Analisis Hubungan Internasional, 7(3), 202.

Balat, M. (2006). The position of oil in the Middle East: potential trends, future perspectives, market and trade. Energy Sources, Part A, 28(9), 821-828.

Budiardjo, M. (2003). Dasar-dasar ilmu politik. Gramedia pustaka utama.

Citradi, T. W. G. (2019). Top! Uni Emirat Arab Era 1960-an Naik Unta, Kini Kaya Raya. Retrieved from cnbcindonesia.com website: https://www.cnbcindonesia.com/news/2019 0910153307-4-98378/top-uni-emirat-arabera-1960-an-naik-unta-kini-kaya-raya
Grant, J., Golawala, F. S., \& McKechnie, D. S. (2007). The United Arab Emirates: the twenty-first century beckons. Thunderbird International Business Review, 49(4), 507533.

HN, S. (2016). Perekonomian Uni Emirat Arab, Kemegahan Dunia di Semenanjung Arab. Retrieved from ajarekonomi.com website: https://www.ajarekonomi.com/2016/10/pere konomian-uni-emirat-arab-

kemegahan.html\#: :text=Perekonomian

Uni Emirat Arab\%2C Kemegahan Dunia di Semenanjung Arab,-Beberapa negara di\&text=Sementara berdasarkan data the International,kapita mencapai US\%24 67.94 ribu.

Insani, R. N., \& Indra, I. (2015). Analisis FaktorFaktor yang Memengaruhi Tingkat Pertumbuhan Ekonomi pada 20 Negara OKI Tahun 2009-2013. Muqtasid: Jurnal Ekonomi Dan Perbankan Syariah, 6(2), 141-156.

Istadiyantha. (2010). Permasalahan Istilah Timur Tengah. Jurnal CMES (Jurnal Studi Timur Tengah), 1(2), 177-190. Retrieved from https://digilib.uns.ac.id/dokumen/download/ 264715/MjYONzE1

ITPC DUBAI - UNITED ARAB EMIRATES MARKET BRIEF 2013. (n.d.). Retrieved from

http://djpen.kemendag.go.id/membership/d ata/files/7c6da-MB-ITPC-DUBAI-112013.pdf

Kuswono, K., Saputra, K. A., \& Agustono, R. (2019). Menyandingkan Ajaran Islam dan Komunisme: Pemikiran Haji Misbach (1912-1926). Criksetra: Jurnal Pendidikan Sejarah, 8(2), 58-69.

Lestari, E. V. (2020). Negara Islam Terkaya di Dunia, Uni Emirat Arab Bukan yang Pertama.

Padjadjaran, T. P. S. T. T. U. (n.d.). Sekilas Mengenai Studi Timur Tengah. Retrieved from https://fisip.unpad.ac.id/pusdi/pstt/wpcontent/uploads/2018/10/Download_SEKIL AS-MENGENAI-STUDI-TIMURTENGAH.pdf

Paryadi, D. (2019). Dampak Kerja Sama Perdagangan Indonesia dengan Negara Gulf Cooperation Council (GCC). Kajian Ekonomi Dan Keuangan, 2(3), 210-225. 
Pradana, A. M. N., \& Yulianti, D. (2017). Peran Liga Arab Pada Konflik di Timur Tengah Dalam Perspektif Ekonomi-Politik Internasional. Jurnal ICMES, 1(1), 99-120.

Pratama, M. F. (2004). Kebijakan Sheikh Zayed 1971-2004: Bidang politik, ekonomi , sosial budaya Uni Emirat Aarab. Universitas Indonesia.

Raharjo, R. O., \& Jamal, M. (2018). PERKEMBANGAN DAN TANTANGAN BANK SYARIAH DI TIMUR TENGAH. PROCEEDING AFRO-ASIAN UNIVERSITY FORUM, 960.

Rohman, F. (2017). CORPORATE GOVERNANCE DAN KINERJA KEUANGAN PADA PERBANKAN DI UNI EMIRAT ARAB. Jurnal Bisnis Dan Manajemen (Journal of Business and Management), 15(2), 79-98.

Ruslin, I. T. (2013). Memetakan Konflik di Timur Tengah (Tinjauan Geografi Politik). JPP (Jurnal Politik Profetik), 1(1).

Safitry, S. N., \& Haryanto, A. (2019). Perbandingan Nitaqat dan Tawteen. Jurnal ICMES, 3(2), 160-183.

Sejarah dan Perkembangan Uni Emirat Arab. (n.d.). Retrieved from http://repository.umy.ac.id/bitstream/handle/ 123456789/21397/6.

$\mathrm{BAB}$ II.pdf? sequence $=6$ \&isAllowed $=y$

Sejarah, T. D. (2013). Pengantar Ilmu Sejarah. Makassar: Universitas Negeri Makassar.

Triyono, A. (2018). PELIPUTAN MEDIA ONLINE ATAS KEBIJAKAN POLITIK RI TERHADAP KRISIS QATAR UNTUK MENDUKUNG DIPLOMASI INTERNASIONAL. Jurnal Egaliter, 1(2).

Tumanggor, F. A. (2018). Dampak Kebijakan Embargo Negara Arab Terhadap Situasi Ekonomi Qatar. Universitas Sumatera Utara.

Uni Emirat Arab PDB Nominal. (2020). Retrieved from ceicdata.com website: https://www.ceicdata.com/id/indicator/unite d-arab-emirates/nominal-gdp

Wening, T. (2010). Kisah Pengalaman Pekerja Domestik Migran Indonesia (Studi Kasus di Penampungan Abu Dhabi, Uni Emirat Arab). Retrieved from http://lib.ui.ac.id/file?file=digital/135773-T 28010-Kisah pengalaman-Abstrak.pdf
Wibowo, P. (2010). Fenomena Neorevivalisme Islam dalam Dunia Internasional. Jurnal Global Dan Strategis, 4(2), 169-188. 